\title{
KONTRIBUSI TEORI SANKSI DAN ASAS PEMBUKTIAN TERHADAP JARIMMAH KORUPSI DI INDONESIA
}

\author{
Nasrullah \\ Sekolah Tinggi Agama Islam Negeri Malikussaleh Aceh, Indonesia \\ E-mail: nasrullah_arull@yahoo.com
}

\begin{abstract}
Islamic law consists of a set of norms, principles and rules of law enforcement, dealing with the eradication of corruption. In the history of Islamic law, there have been the theories and principles of Islamic law, such as the theory of jawâbir, zawajïr, and the principle of min ayn lak hâdhâ (known as the reversed evidence) regarding the application of criminal sanctions of corruption. The application of criminal sanctions of corruption in Indonesia, especially with regard to the principle of reversed evidence has not been well-formulated. For the perfection of legislation in combating corruption, it is possible for the Indonesian government to amend the existing legislation, in order to make the country free from corruption. This paper focuses on the study of theoretical contributions on sanctions and the principle of proof evidence in Islamic criminal law to be transformed into criminal sanctions of corruption in Indonesia, which refers to the theory of jawâbir, zawajij, and the principle of min ayn lak bâdh $\hat{a}$, which had been done previously by the caliph 'Umar b. al-Khațâb and succeeded in preventing and combating corruption.
\end{abstract}

Keywords: Corruption; reversed proof; Islamic theories of jawâbir and zawâjir.

\section{Pendahuluan}

Bentuk-bentuk pidana korupsi pada masa awal Islam, terutama masa Nabi Muhammad, dikenal dengan beberapa istilah yang mempunyai konotasi sebagai unsur tindak pidana korupsi, seperti rishwah, ghulul, ghasab, khiyânah, dan sariqah. ${ }^{1}$ Akan tetapi sanksinya lebih

\footnotetext{
${ }^{1}$ Rofiqul 'A'la, "Suap dalam Pespektif Islam” dalam A.S. Burhan dkk, ed., Korupsi di Negeri Kaum Beragama: Ikhtiar Membangun Fiqh Anti Korupsi Jakarta: P3M dan Kemitraan-Partnership, 2004), 182.
} 
ditekankan kepada ancaman moral, sosial, dan ukhrawi, ${ }^{2}$ seperti tidak diterimanya sedakah dari hasil korupsi, pelakunya dilaknat Allah, pelaku korupsi akan datang pada hari kiamat dengan membawa barang korupsi, dan sebagainya. Penerapan sanksi yang membuat jera koruptor pada saat itu tidak pernah diberlakukan. Hal ini memang wajar karena orang-orang yang menjadi pembantu Nabi Muhammad adalah orang yang terpercaya dan merupakan para sahabat yang mulia, sehingga Nabi, sebagai pembawa risalah Allah, hanya menitikberatkan pada konsep ta'dî́b (mendidik) dan mencegah sahabatnya untuk tidak melakukan perbuatan korupsi.

Tujuan utama penetapan dan penerapan sanksi pidana Islam kepada pelaku korupsi sendiri, pada dasarnya, adalah untuk mendidik pelaku jarimah agar ia takut terhadap hukuman dan menyadari kesalahannya serta mengembalikan hak orang lain yang telah diambilnya. Hukuman yang diberikan merupakan pembalasan yang sepadan dengan perbuatannya. Hal ini seperti dijelaskan dalam Q.S. alZalzalah [99]: 7-8 dan Q.S. al-Shûrâ [42]: 40. Dalam rangka melakukan perbaikan dan pendidikan bagi pelaku korupsi, maka penerapan sanksi pidana korupsi harus memiliki efek jera bagi pelaku dan sekaligus dapat menjadi pelajaran bagi orang lain. ${ }^{3}$

Sepeninggal Nabi Muhammad, kekuasaan pemerintahan Islam berikutnya beralih kepada al-Khulafâ' al-Râshidûn. Pada saat kekhilafahan kedua, yang dikomando oleh 'Umar b. al-Khațtâb, muncul suatu konsep atau asas min ayn lak hâdhâ sebagai bentuk hukum berkaitan penerapan sanksi pidana korupsi. ${ }^{4}$ Konsep yang diterapkan oleh 'Umar tersebut telah mengantarkan negara dan pemerintahan yang dipimpinnya saat itu tertata rapi dan bersih dari tindakan korupsi. Hal itu dikarenakan 'Umar tidak segan menjatuhkan sanksi kepada para bawahannya bila mereka benar-benar terbukti telah melakukan korupsi. $^{5}$

\footnotetext{
2 Bandingkan dengan M. Nurul Irfan, Korupsi dalam Hukum Pidana Islam (Jakarta: Amzah, 2011), 135-140.

3 Ahmad Azhar Basyir, Ikhtisar Fikih Jinayat: Hukum Pidana Islam (Yogyakarta: UII Press, 2001), 66.

${ }^{4}$ Lebih lanjut lihat Muhammad Saî̀d Mursî, Tokoh-tokoh Besar Islam Sepanjang Sejarah, terj. Khoirul Amru Harahap dan Achmad Faozan (Jakarta: Pustaka Al-Kautsar, 2007), 15.

5 Muhammad Baltaji, Metodologi Ijtihad Umar bin al-Khathab, terj. Masturi Irham (Jakarta: KHALIFA, 2005), 427 dan 429-430.
} 
Dalam literatur fiqh jinâyah (hukum pidana Islam) terdapat dua teori lain yang lebih spesifik menyangkut penerapan sanksi pidana korupsi, yaitu teori zawajjir (pidana yang ditujukan untuk tujuan pencegahan, baik secara umum maupun khusus) dan jawâbir (pidana yang ditujukan untuk pembalasan). ${ }^{6}$ Sementara itu, makna dasar asas min ayn lak hâdhâ yang berarti "dari mana kamu peroleh harta ini?"7 merupakan asas penting menyangkut pertanggungjawaban seorang pejabat negara/pejabat publik terhadap harta yang dia miliki di akhir masa jabatannya. Asas ini pada intinya selaras dengan teori pembuktian terbalik.

Dalam konteks Indonesia, terutama pada saat pemerintahan Presiden Susilo Bambang Yudhoyono jilid II, penerapan sanksi pidana korupsi bagi pelaku tindak pidana korupsi (Tipikor)—meskipun belum mencapai hakikat tujuan hukum-telah menunjukkan keseriusan. Hal tersebut dapat dilihat dengan dijeratnya banyak pelaku tindak pidana korupsi besar dengan pasal-pasal hukum Tipikor. Namun di masa pemerintahan Jokowi-Jusuf Kalla, harapan itu terhenti akibat perseturuan antara Komisi Pemberantasan Korupsi (KPK) dan Kepolisian Republik Indonesia (Polri), dan sampai sekarang penegakan hukum belum berjalan lancar sebagaimana harapan publik. Ke depan-menurut hemat penulis-KPK, jaksa, dan hakim memerlukan kerja ekstra keras agar di strata manapun tindak pidana korupsi ditindak dan diadili sesuai dengan sanksi yang berlaku. Apabila masih terdapat kelemahan dalam penerapan sanksi korupsi, maka perlu diadakan pengujian dan perbaikan materi hukum melalui lembaga yang berkompeten. Oleh karena itu, agar materi hukum tentang sanksi pidana korupsi semakin sempurna dan bertahan lama, maka tidak menutup kemungkinan dilakukan penyerapan teori-teori dan asas hukum Islam ke dalam penerapan sanksi pidana korupsi di Indonesia.

Masalah ini menarik untuk dikaji secara komperehensif. Hal ini mengingat bahwa teori dan asas hukum Islam tentang penerapan sanksi pidana korupsi bersifat elastis, dinamis, sistematis, dan memiliki masa depan khususnya bagi negara Indonesia yang berpenduduk mayoritas Muslim. Dengan kata lain, teori dan asas hukum Islam tentang penerapan sanksi pidana korupsi sangat mungkin untuk ditransformasikan ke dalam peraturan undang-undang pemberantasan

\footnotetext{
${ }^{6}$ Juhaya S. Praja, Teori-teori Hukum: Suatu Telaah Perbandingan dengan Pendekatan Filsafat (Bandung: Pascasarjana Universitas Islam Negeri, 2009), 111.

${ }^{7}$ Baltaji, Metodologi Ijtihad, 424-425.
} 
tindak pidana korupsi di Indonesia sebagai proses law enforcement (penegakan hukum).

\section{Kontribusi Teori dan Asas Pembuktian Korupsi di Indonesia}

Dalam rangka mengefektifkan penerapan hukum pemberantasan tindak pidana korupsi di Indonesia, terdapat dua teori dan satu asas dalam hukum Islam yang bisa diadopsi berkaitan dengan jarimah korupsi, yaitu teori zawâjir dan jawâbir serata asas min ayn lak hâdhâ sebagaimana disebutkan di atas. Kedua teori itu muncul ketika ulama fiqh membahas sifat hukum dalam berbagai tindak pidana, yaitu apakah ia bersifat preventif atau paksaan (balas dendam), begitupun dengan hukuman yang telah dilaksanakan di dunia, apakah pelakunya masih akan disiksa di akhirat atau terbebas. Apabila dikaitkan dengan hukum pidana umum, teori zawâjir dan jawâbir dapat disepadankan dengan teori retributif dan utilitarian yang dikenal dalam teori pemidanaan serta dikembangkan dalam hukum pidana. ${ }^{8}$

Dalam implimentasinya, teori jawajïr dan zawâbir memiliki perbedaan yang signifikan. Hal ini seperti dikemukakan Juhaya S. Praja, yaitu:

a. Zawâjir disharî‘ahkan sebagai pencegahan terhadap tindak pidana yang akan terjadi, sedangkan jawâbir disharî́ahkan untuk mencapai kemaslahatan.

b. Zawâbir ditetapkan untuk perbuatan yang melanggar ketentuan Allah, sehingga dengan menghukum pelanggarnya orang lain akan mendapat pelajaran dan berusaha untuk menghindari perbuatan itu. Adapun zawajjir umumnya dikenakan pada seluruh pelaku pidana tanpa pandang bulu.

c. Zawajjir berkaitan dengan tindak pidana terhadap jiwa anggota badan, manfaat dari anggota badan, ibadah, harta dan manfaat. Adapun jawâbir berkaitan dengan pelanggaran jinâyah dan sikapsikap yang bertentangan dengan kehendak shar', seperti pembunuhan, zina, pencurian, perampok, pemberontakan, menuduh orang lain berbuata zina (qadbf), mengambil harta orang lain tanpa izin (ghasab) dan minum minuman keras.

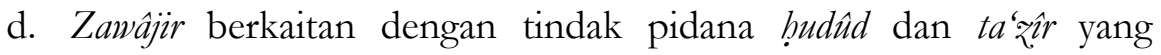
hukumannya dilaksanakan oleh hakim. Sedangkan jawâbir ditujukan

8 Muhammad Din, Stimulasi Pembangunan Hukum Pidana Nasional dari Aceh untuk Indonesia (Bandung: UNPAD PRESS 2009), 82; Taqwaddin, Esensi Hukum Rajam (Lhokseumawe: Serambi, 2009), 24. 
terhadap tindak pidana yang pelaksanaan hukumannya diserahkan kepada orang yang dirugikan.

e. Zawajïr dalam masalah manfaat seperti seseorang yang menempati rumah orang lain tanpa izin dikenakan ganti rugi biaya, selama rumah itu ditempatinya. Contoh lain adalah untuk jiwa anggota badan dan manfaat anggota badan ialah denda (diyat) atau kaffarah. Adapun hukuman terhadap pembunuhan yaitu qisas s.s termasuk ke dalam kategori zawâjir.

Apabila diperhatikan bentuk-bentuk hukuman yang ditentukan oleh Allah dan Rasul-Nya bagi pelanggar pidana hudûd, terutama menurut teori zawajior dan jawâbir, maka terlihat bahwa hukuman yang harus diterima terpidana lebih berat dibandingkan dengan tindak pidana yang ia lakukan. Dalam konteks ini, tujuan utama penentuan hukuman adalah sebagai tindakan preventif di mana orang lain tidak akan melakukan tindak pidana yang sama setelah ia melihat pelaksanaan hukuman terhadap terpidana qișâs yang dilaksanakan di hadapan khalayak ramai. Artinya, hal tersebut dapat dijadikan pelajaran oleh masyarakat secara luas. Hal ini sesuai dengan firman Allah dalam Q.S. al-Baqarah [2]: 179.

Ulama mazhab Hanafî berpendapat bahwa tindak pidana ḩudûd dan $t a$ ' $2 \hat{\imath}$ disharî́ahkan semata-mata sebagai tindak pencegahan bagi masyarakat di dunia, meskipun dosa terpidana sendiri tidak hilang kecuali melalui tobat. Namun demikian jumbûr ulama berpendapat bahwa hukuman yang telah ditentukan itu selain sebagai tindakan preventif di dunia juga bisa menghapuskan hukuman di akhirat apabila ia telah dilaksanakan di dunia. Pendapat jumbûr ulama tersebut didasarkan pada sabda Nabi Muhammad yang berbunyi:

$$
\begin{aligned}
& \text { تبايعونى على ان لا تشركوا بالله شيا ولا تزنوا ولا تسر قوا ولا تقتلوا النفس التى حرم الله }
\end{aligned}
$$

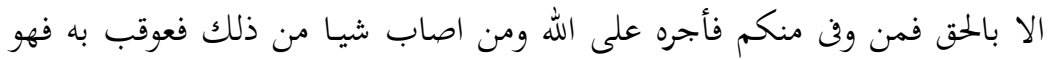

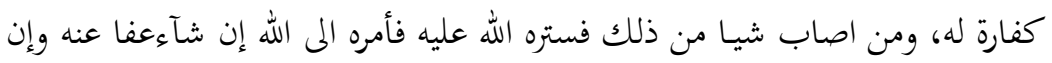

$$
\begin{aligned}
& \text { شاءعذبه } 10 .
\end{aligned}
$$

Berjanjilah kamu sekalian di hadapanku untuk tidak menyekutukan Allah, untuk tidak berzina, untuk tidak mencuri dan untuk tidak

\footnotetext{
${ }^{9}$ Praja, Teori-teori Hukum, 112-113.

${ }^{10}$ Abû 'Abd Allâh Muhammad b. Ismâ‘̂il b. Ibrâhîm b. Mughîrah al-Bukhârî, Ṣahîh alBukhârî, Vol. 1 (t.t.: Dâr al-Fikr, t.th.), 18; 'Abd al-Ḥusayn Muslim b. al-Hạj)âj, Ṣaḥ̣̣̂̂ Muslim, Vol. 5 (Damaskus: Dâr al-Fikr, t.th.), 126.
} 
membunuh nyawa yang diharamkan oleh Allah, kecuali dengan benar. Barangsiapa yang teguh dengan janji-janjinya itu, maka balasannya tersedia di sisi Allah. Tetapi barangsiapa yang melanggar salah satu janji, maka ia dikenai hukuman sebagai penghapusan dosa tersebut baginya. Barangsiapa yang masih juga melanggar janji-janjinya itu, tetapi ditutupi oleh Allah, maka persoalannya terserah pula kepada Allah. Jika Dia menghendaki untuk mengampuninya, maka ia diampuni-Nya, dan jika sebaliknya, maka orang yang bersangkutan itu akan disiksa. (HR. Bukhârî dan Muslim)

Pandangan jumbûr ulama mengenai hadîth tersebut menyiratkan bahwa penerapan sanksi terhadap suatu tindak pidana, korupsi misalnya, tampaknya lebih mempertimbangkan aspek zawâjir di akhirat, dan tidak mempertimbangkan penerapan hukuman di dunia sebagai jawâbir. Bahkan menurut kedua teori tersebut, sanksi pidana korupsi dalam hukum Islam bisa lebih berat jika dibandingkan dengan hukum pidana yang diterapkan di Indonesia. Menurut penulis, pendapat tersebut bisa dibenarkan karena penerapan sanksi pidana bagi pelaku korupsi berdasarkan hukum Islam, kiranya, hanya akan menjadi pilihan terakhir dan/atau termasuk hal pokok (darûriyyat). ${ }^{11}$

Ditegaskan kembali bahwa teori zawajjir dan jawâbir saling berkaitan sebagai bentuk pencegahan. Apabila seseorang melakukan suatu tindak pidana, maka diberikan kepadanya pembalasan dengan hukuman yang ditentukan; termasuk dalam hal ini adalah penerapan hukuman minimal sampai hukuman maksimal. Hal ini sesuai dengan tujuan penerapan hukum itu sendiri, yakni tidak hanya dalam rangka memberikan efek jera (deterrence effect) tetapi juga pencegahan (preventive effect) untuk kemaslahatan umum. ${ }^{12}$

Kembali kepada asas min ayn lak hâdhâ yang muncul sejak kekuasaan Islam berada di tangan amîr al-mukminin 'Umar b. alKhatțâb di mana dalam perkembangannya asas ini dijadikan sebagai usaha pencegahan sekaligus pemberantasan korupsi dalam perspektif hukum Islam. 'Umar membuat ketetapan dan aturan itu untuk para pegawainya (gubernur) untuk tidak hidup dalam kemewahan dan tidak menerima hadiah, melainkan hanya mengambil materi secukupnya dan

11 Abû Ishậq al-Shâtịîi, al-Muwâfaqât fî Ușûl al-Sharîah, Vol. 2 (Beirût: Dâr al-Kutûb al-'Ilmîyah, t.th.), 7.

12 'Ațiyah Muștafâ Musharrafah, al-Qậa fî al-Islâm (T.tp: Shirkah al-Sharq al-Awsât, 1966), 149. Lihat juga 'Abd al-'Azîz al-'Amîr, al-Ta'zîr fì al-Sharî'ah al-Islâmîyah (Kairo: Dâr al-Fikr al-“Arabî, 1976), 52; Muștafâ Aḥmad al-Zarqâ, al-Madkhal al-Fiqhî al-'Âm, Vol. 2 (Damaskus: Dâr al-Fikr, Cet. Ke-2, 1968), 626. 
selebihnya diserahkan untuk kemaslahatan umum. ${ }^{13}$ Inisiatif, kecerdasan, dan keberanian 'Umar tersebut merupakan usaha penciptaan clean good governance agar roda pemerintahan yang ia jalankan bersih dan para pejabat publik terhindar dari perilaku korup.

Selain usahanya dalam menciptakan clean good governance melalui tindak pencegahan dan pemberantasan korupsi, 'Umar juga membuat langkah strategis dalam kaitannya dengan politik ketatanegaraan. Langkah-langkah tersebut di antaranya adalah pemisahan kekuasaan eksekutif, legilatif, dan yudikatif di mana pada akhirnya hal ini membentuk sebuah negara yang dalam masa modern disebut "republik". Pemisahan kekuasaan tersebut dilakukan oleh 'Umar jauh sebelum dikenal adanya konsep trias politica yang diperkenalkan para pemikir Barat semisal Montesquieu. ${ }^{14}$ Menurut hemat penulis, pemisahan kekuasaan antara tiga penyelenggara negara tersebut dilakukan 'Umar dalam rangka mendukung dan memudahkan usahanya menciptakan pemerintahan yang bersih dari berbagai tindak pidana yang merugikan publik, terutama tindak pidana korupsi. Berbagai segi kehidupan pemerintahan, seperti sistem keuangan, parsitipasi perempuan dalam kehidupan sosial, dan hak-hak yang diperoleh kaum non-Muslim (dhimmi) juga tidak luput dari perhatian 'Umar. Selain hal-hal tersebut, 'Umar juga telah melalukan beberapa ijtihad yang menunjukkan kecemerlangan pemikirannya, seperti:

a. Menetapkan tahun hijrah sebagai kalender (sistem penanggalan) Islam;

b. Mengumpulkan kaum Muslim dalam salat taraweh dan menyinari masjid-masjid di malam Ramadhan;

c. Mengumpulkan kaum Muslim untuk melakukan salat jenazah dengan empat takbir;

d. Menghentikan pemberian zakat kepada orang-orang yang baru masuk Islam (al-mu'allaf qulübubum) berdasarkan kausa hukumnya (illat-nya) telah hilang;

e. Memberikan hadiah kepada para penghafal al-Qur'ân;

f. Menjadikan urusan pengangkatan khalifah di tangan beberapa orang tertentu;

g. Menjadikan talak tiga dengan satu lafal menjadi talak bâ'in;

${ }^{13}$ Mursî, Tokoh-tokoh Besar Islam, 13.

${ }^{14}$ Azyumardi Azra, "Umar bin Khattab: Konsep dan Praksis Ketatanegaraan”, dalam Hasbi Amiruddin, Republik. Umar bin Khattab (Yogyakarta: Total Media, 2010), ix. 
h. Memerintahkan untuk menceraikan wanita abl al-kitâb dan melarang untuk menikahi mereka;

i. Menghukum orang yang mengejek;

j. Mengambil zakat kuda;

k. Menjadikan pajak dalam beberapa tingkatan sesuai dengan kemampuan ekonomi rakyat;

1. Menggugurkan wajib pajak dari orang-orang miskin, abl al-dhimmah, dan kaum papa;

m. Mendirikan pangkalan militer, mengintruksikan wajib militer, membuka kantor administrasi militer, mengkhususkan beberapa tenaga medis, hakim, dan juru dakwah bagi para prajurit;

n. Mendirikan Bayt al-Mâl untuk kaum Muslimin;

o. Mencetak mata uang Dirham;

p. Menetapkan pemberian khusus bagi setiap bayi yang lahir dalam Islam;

q. Memberikan belanja kepada anak pungut yang diambil dari Bayt alMâl;

r. Menyuruh untuk membunuh sekelompok orang yang bersengkongkol membunuh orang lain;

s. Menyuruh untuk membunuh wanita yang berprofesi sebagai dukun (paranormal);

t. Orang pertama yang mencambuk orang yang memalsukan stempel resmi negara; dan

u. Mengaudit kekayaan para pejabat dan pegawai negara dan mengundangkan Undang-undang min ayn lak hâdhâ. ${ }^{15}$

Beberapa pemikiran 'Umar di atas menunjukkan bahwa dengan sifat dan karakternya yang berani, gigih, dan tegas telah berhasil merobah tatanan kehidupan bernegara dan beragama pada saat itu. Dalam aspek hukum banyak ditemukan ijtihad 'Umar meskipun jika dilihat dari metode penalaran bayânî (kebahasaan) berbeda. 'Umar lebih mendepankan metode penalaran istișlâhı̂ (kemaslahatan) bagi tatanan kehidupan masyarakat waktu itu. Dalam kaitan itu, 'Umar dikenal tidak hanya sukses dalam mengelola negara selama masa kepemimpinannya, namun ia juga sukses dalam memberantas korupsi melalui penerapan asas min ayn lak hâdhâ, salah satu ijtihad terpenting 'Umar dalam bidang pemerintahan.

Usaha pemberantasan korupsi yang dilakukan oleh 'Umar, baik dalam bentuk ghulûl maupun pemberian hadîyah (seperti yang sekarang

${ }^{15}$ Mursî, Tokoh-tokoh Besar Islam, 15. 
marak terjadi di Indonesia dan disebut dengan istilah gratifikasi), ${ }^{16}$ pada dasarnya lebih menekankan sisi pencegahan, meskipun memang terdapat adanya unsur penghukuman, seperti pemecatan dari jabatan, karena seorang pejabat telah melanggar syarat-syarat dan aturan-aturan yang telah ia tetapkan. Pemberantasan tindak pidana korupsi di masa 'Umar menjadi salah satu prioritas utama. Begitu ketatnya pengawasan sampai-sampai ia merasa penting untuk mengangkat seorang petugas (pegawai) yang sangat dipercaya, yaitu Muhammad b. Maslamah. Maslamah diberi tugas mencatat kekayaan para gubernur pada saat diangkat dan berakhirnya jabatan serta mengawasinya. ${ }^{17}$ Dalam konteks Indonesia, posisi Maslamah tersebut dikenal dengan istilah penilik dan badan pengawas pekerja, dan/atau KPK. Pemberantasan tindak pidana korupsi memang membutuhkan keberanian yang tangguh serta perasaan tidak gentar menghadapi siapapun yang melakukannya. ${ }^{18}$ Keberanian seorang pemimpin dan petugas pemberantasan korupsi dalam mengatakan kebenaran dengan tegas serta kekuatan menahan godaan suap merupakan modal yang paling penting selain mereka sendiri harus bersih dari tindakan korupsi.

Asas min ayn lak hâdhâ atau dalam sejarah hukum Islam dikenal sebagai "pembuktian terbalik", merupakan gagasan yang dicetuskan 'Umar bin Khațâb dalam pemerintahannya, yaitu menyusun sebuah perundang-undangan yang berkaitan dengan harta (penyitaan harta), agar harta tersebut terjaga, tidak terjadi kebocoran, dan tidak diambil oleh bawahannya secara semena-mena tanpa alasan tertentu. Langkah yang dilakukan 'Umar ini sangat strategis sebagai upaya pemberantasan korupsi terhadap harta negara. Penetapan aturan penyitaan harta pejabat itu tidak hanya didasarkan atas kecurigaan atau dugaan (zann) 'Umar, akan tetapi berdasarkan bukti shar'î, yakni bukti tertulis berupa pencatatan (hasil audit) sebagai bentuk preventif terjadinya korupsi. Sebagai seorang pemimpin yang sangat ketat dalam mengawasi dan mengontrol bawahannya, Ibn Sa'âd di dalam kitab Tâabaqat

\footnotetext{
${ }^{16}$ Lihat Nasrullah, "Tindak Pidana Korupsi dalam Hukum Islam dan Peraturan Perundang-undangan Republik Indonesia: Studi Kritis Hukum Islam terhadap Undang-undang No. 31 Tahun 1999 Jo Undang-undang No. 20 Tahun 2001 tentang Pemberantasan Tindak Pidana Korupsi”, Disertasi (Banda Aceh--Program Pascasarjana IAIN Ar-Raniry, 2013), 347.

17 Ibn Abî al-Ḥadîd, Sharḥ Nahj al-Balâghah, Vol. 1 (Kairo: Dâr Ihyyâ' al-Kitâb al'Arabîyah, 1959), 177-178.

${ }^{18}$ Hasbi Amiruddin, Republik Umar bin Khattab (Yogyakarta: Total Media, 2010), $106-$ 107.
} 
menuturkan kesaksian dari al-Shi'bî̀, bahwa 'Umar setiap kali mengangkat kepala daerah selalu mencatat kekayaan orang tersebut. Untuk kelancaran menangani hal tersebut, 'Umar mengangkat seorang pegawai khusus yang bertugas sebagai auditor.

Berdasarkan catatan tersebut, penyidikan yang dilakukan 'Umar adalah menyita kelebihan harta kekayaan pejabat-pejabat yang diragukan perolehannya. 'Umar selalu menghitung dan mencatat kekayaan seseorang sebelum diangkat menjadi pejabat negara atau penguasa daerah. ${ }^{19}$ Ketika masa tugasnya berakhir, 'Umar mencatat kembali kekayaan pejabat tersebut. Apabila dalam pencatatan itu ditemukan kelebihan harta yang meragukan, 'Umar menyita harta tersebut dan/atau dibagi menjadi dua di mana setengah untuk pejabat bersangkutan dan setengahnya lagi untuk Bayt al-Mâl. Para pejabat yang berkunjung ke daerah pun tidak luput dari pengawasan 'Umar, seperti kasus Abû Sufyân (ayah Mu'âwîyah) gubernur di Syam. Dalam sebuah riwayat disebutkan bahwa Abû Sufyân pernah diperiksa langsung oleh 'Umar ketika kembali dari Syam setelah mengunjungi anaknya $\mathrm{Mu}$ 'âwîyah. 'Umar mendatangi Abû Sufyân dan berkata "Berikanlah barang-barang yang kamu bawa itu, wahai Abû Sufyân". Abû Sofyân menjawab, "Aku tidak membawa apapun. Maka apa yang harus aku serahkan?" 'Umar tidak percaya begitu saja, lalu mengambil cincin dari Abû Sufyân lalu menyuruhnya memberikan tersebut kepada isterinya dan kemudian memerintahkan Abû Sufyân dengan berkata: "Berikanlah kepadaku dua karung yang kalian bawa dari Syam". Setelah karung diperiksa ternyata ditemukan 10.000 dirham. Karena setelah dihitung pendapatan $\mathrm{Mu}$ 'âwîyah tidak sebanyak itu, maka 'Umar mengambilnya dan menyerahkannya kepada Bayt al-Mâl. ${ }^{20}$

Perbuatan 'Umar tersebut mengindikasikan pembuktian terbalik dalam kasus tindak korupsi. Namun di sisi lain-dengan tetap memperhatikan dalil-dalil yang ada—seorang hakim (qâdı) dilarang menjatuhkan vonis hukum kepada terdakwa sebelum adanya bukti shar'î yang jelas. Menjatuhkan vonis pada dasarnya adalah karena si terdakwa dinyatakan telah bersalah secara hukum dan untuk membuktikan itu, khususnya dalam kasus tindak korupsi, hakim dapat menerapkan asas pembuktian terbalik. Sandaran hukum mengenai

19 Jalâl al-Dîn al-Suyûṭ̂, Târîkh al-Khulafâ' (Kairo: Dâr al-Kutûb al-Salafiyah, t.th.), 132 .

${ }^{20}$ Amiruddin, Republik Umar bin Khattab, 113. 
pembuktian terbalik dapat mengacu kepada perbuatan 'Umar, yaitu dengan konsep min ayn lak hâdhâ, agar tindak pidana korupsi dapat dicegah dan diberantas sedini mungkin. Penerapan asas ini tidak hanya memungkinkan bagi hakim untuk menjadikannya sebagai alasan pertimbangan dalam putusannya akan tetapi juga sangat memungkinkan bagi pemerintah untuk mentransformasikannya ke dalam bentuk legislasi.

Untuk menghindari kesalahan kebijakan legislasi, pasal yang menghendaki adanya pembuktian terbalik tidak boleh mencantumkan delik inti di dalamnya, karena itu merupakan tugas Jaksa Penuntut Umum. Seorang terdakwa juga tidak boleh dipaksa membantu apa yang dituduhkan kepadanya dengan memaksakan prinsip pembuktian terbalik karena akan bertentangan dengan asas non self-incrimination. Dengan demikian, pada akhirnya, aspek hukum yang perlu dibidik oleh pihak penegak hukum adalah bagaimana mendorong si terdakwa membuktikan ketakbersalahannya dalam hubungan dengan jabatannya dan adanya kewajiban yang bertentangan, baik dalam pengertian fungsi hukum positif maupun negatif.

Salah satu faktor yang menyebabkan sulitnya mengusut tindak pidana korupsi adalah sulitnya menemukan bukti atau membuktikan adanya tindak pidana korupsi itu sendiri. Membuktikan, menurut Martiman Prodjohamidjojo, mengandung maksud usaha untuk menyatakan kebenaran atas suatu peristiwa sehingga dapat diterima oleh akal terhadap kebenaran peristiwa tersebut. ${ }^{21}$ Sedangkan Bambang Poernomo menyatakan bahwa:

Hukum pembuktian adalah keseluruhan aturan hukum atau peraturan Undang-undang mengenai kegiatan untuk rekonstruksi suatu kenyataan yang benar dari setiap kejadian masa lalu yang relevan dengan persangkaan terhadap orang yang diduga melakukan perbuatan pidana dan pengesahan setiap sarana bukti menurut ketentuan hukum yang berlaku untuk kepentingan peradilan dalam perkara pidana. ${ }^{22}$

Oleh karena itu, pembuktian tentang benar atau tidaknya terdakwa melakukan perbuatan yang didakwakan merupakan bagian yang terpenting dari acara pidana. Dalam hal ini, hak asasi manusia dipertaruhkan. Hukum Acara Pidana bertujuan untuk mencari kebenaran materil. Hal ini berbeda dari Hukum Acara Perdata yang

21 Martiman Prodjohamidjojo, Sistem Pembuktian dan Alat Bukti (Jakarta: Ghalia Indonesia, 1983), 11.

22 Bambang Poernomo, Pertumbuhan Hukum Penyimpangan di Luar Kodifikasi Hukum Pidana (Jakarta: Bina Aksara, 1986), 38. 
mencukupkan diri pada kebenaran formil. Kebenaran dalam perkara pidana merupakan kebenaran yang disusun dan didapatkan dari jejak, kesan, dan refleksi dari keadaan dan/atau benda yang berdasarkan ilmu pengetahuan dapat berkaitan dengan kejadian masa lalu yang diduga menjadi perbuatan pidana.

Asas praduga tak bersalah seperti dipahami dalam hukum pidana yang ada, ${ }^{23}$ pada dasarnya telah terlebih dahulu dilakukan 'Umar terutama berkenaan dengan kepemilikan harta yang didapatkan atau ketika seorang pejabat publik memiliki kekayaan tidak wajar. Apabila terdapat indikasi adanya kekayaan yang tidak sah, maka pemilik kekayaan harus dapat membuktikannya dengan menggunakan pendekatan pembuktian terbalik. Metode pembuktian terbalik dilakukan apabila dalam penyidikan suatu kasus korupsi penuntut belum memiliki data-data yang akurat. Hukum pidana yang dimaksud adalah Pasal 66 KUHAP yang menjelaskan bahwa tersangka atau terdakwa tidak dibebani kewajiban pembuktian. Menurut penjelasan pasal tersebut, ketentuannya merupakan penjelmaan dari asas "praduga tak bersalah". Asas tersebut diatur dalam penjelasan umum butir $3 \mathrm{C}$ KUHAP, yaitu setiap orang yang disangka, ditangkap, ditahan, dituntut dan/atau dihadapkan di muka sidang pengadilan wajib dianggap tidak bersalah sampai adanya putusan pengadilan yang menyatakan kesalahannya dan memperoleh kekuatan hukum tetap. ${ }^{24}$

Asas praduga tak bersalah sendiri juga telah diakui oleh dunia internasional, antara lain diatur dalam Pasal 14 Ayat (2) Perjanjian Internasional tentang Hak-Hak Sipil dan Politik Tahun 1996 yang menjelaskan bahwa setiap orang yang dituduh melakukan pelanggaran pidana akan berhak atas praduga tak bersalah sampai terbukti bersalah menurut hukum. Oleh karena itu, sebagai komponen dasar dari hak atas suatu peradilan yang fair, asas praduga tak bersalah antara lain berarti bahwa beban pembuktian dalam suatu peradilan pidana tergantung pada penuntutan dan si tertuduh mempunyai keuntungan sebagai orang yang diragukan. ${ }^{25}$ Selain itu dalam Pasal 14 Ayat (3)

\footnotetext{
${ }^{23}$ Ibid., 33. Dalam penjelasan di atas terlihat bahwa asas praduga tak bersalah secara tegas telah diatur oleh peraturan perundang-undangan yang tidak hanya diakui di Indonesia tetapi juga diakui di dunia internasional. Asas praduga tak bersalah ini merupakan salah satu bentuk jaminan perlindungan terhadap hak asasi manusia.

${ }^{24}$ M. Sudradjat Bassar, Hukum Pidana: Pelengkap KUHP (Bandung: Armico, 1983), 34.

${ }^{25}$ Lawyer Committee for Human Right, Fair Trial: Prinsip-prinsip Peradilan yang Adil dan Tidak Memihak, terj. Ahmad Fauzan (Jakarta: Yayasan Lembaga Bantuan Hukum Indonesia, 1997), 23.
} 
huruf g, Perjanjian Internasional tersebut dinyatakan bahwa "dalam penentuan tuduhan pelanggaran pidana terhadapnya, setiap orang berhak untuk tidak dipaksa memberikan kesaksian terhadap diri sendiri atau mengaku bersalah." Ketentuan ini sering disebut juga dengan asas non self-incrimination.

Meskipun ketentuan itu tidak secara tegas mengatur tentang bukti yang didapat dengan cara pemaksaan, namun telah lama ditafsirkan bahwa bukti tersebut tidak dapat diterima di pengadilan. Di samping itu, diamnya tersangka atau terdakwa tidak dapat digunakan sebagai bukti untuk menyatakan bersalah. Selain itu, tidak ada konsekuensi yang negatif dapat ditarik dari pelaksanaan hak untuk diam dari seorang tersangka. ${ }^{26}$ Berdasarkan penjelasan di atas terlihat bahwa asas praduga tak bersalah secara tegas telah diatur oleh peraturan perundang-undangan, yang tidak hanya diakui di Indonesia, tetapi juga diakui di dunia internasional. Asas praduga tak bersalah ini merupakan salah satu bentuk jaminan perlindungan terhadap hak asasi manusia.

Meskipun penerapan asas pembuktian terbalik dalam suatu perkara pidana merupakan penyimpangan terhadap asas praduga tak bersalah yang telah diatur dalam KUHAP, tetapi dalam hal ini berlaku asas lex specialist derogat lex generali. Hal ini merupakan salah satu sarana yang dapat ditempuh untuk memberantas korupsi yang sudah mengakar di Indonesia serta sesuai dengan tujuan hukum itu sendiri, yaitu untuk mewujudkan hal berfaedah bagi orang banyak. Karena apa yang berfaedah bagi seseorang mungkin saja merugikan orang lain, maka tujuan dari hukum adalah menjamin kebahagiaan sebanyakbanyaknya bagi orang banyak. ${ }^{27}$ Berkaitan dengan itu, dalam asas pembuktian terbalik, hakim berangkat dari praduga bahwa terdakwa telah bersalah melakukan suatu pelanggaran hukum atau presumption of guilt. Kemudian terdakwalah yang harus membuktikan bahwa dirinya tidak bersalah, dan jika tidak dapat membuktikan, maka ia dinyatakan bersalah tanpa perlu pembuktian lagi dari pihak penuntut umum.

Dengan sistem pembuktian seperti tersebut di atas, sekilas tampak bahwa hak-hak seorang terdakwa tidak dijamin bahkan dilanggar. Padahal, dalam Pasal 183 KUHAP, secara tegas diatur bahwa "Hakim tidak boleh menjatuhkan putusan pidana kepada seseorang kecuali apabila dengan sekurang-kurangnya dua alat bukti

\footnotetext{
${ }^{26}$ Ibid., 33.

27 C.S.T Kansil, Pengantar Ilmu Hukum dan Tata Hukum Indonesia (Jakarta: Balai Pustaka, 1989), 44.
} 
yang sah ia memperoleh keyakinan bahwa suatu tindak pidana benarbenar terjadi dan bahwa terdakwalah yang bersalah melakukannya". Dalam asas pembuktian terbalik ketentuan tersebut memang dikesampingkan, karena hakim dapat saja menjatuhkan putusan pidana tanpa adanya suatu alat bukti, yaitu jika terdakwa tidak dapat membuktikan bahwa dirinya tidak bersalah. Jadi, keyakinan hakim sudah cukup untuk menyatakan kesalahan terdakwa tanpa perlu adanya alat bukti. Hal ini sama dengan sistem dalam asas pembuktian conviction intime (pembuktian berdasarkan pada keyakinan hakim semata).

Menurut Luhut MP, bila sistem pembuktian terbalik itu diterapkan maka akan membawa implikasi negatif yang luar biasa, yaitu: pertama, dalam situasi rendahnya kapabilitas dan integritas aparatur penegak hukum dewasa ini maka sistem pembuktian terbalik bisa menjadi alat black-mailing yang efektif untuk memperkaya diri dan bentuk penyalahgunaan penegakan hukum yang lain. Kedua, usaha untuk meningkatkan profesionalitas dan integritas penegak hukum akan menjadi tidak perlu bila sistem pembuktian terbalik diterima. Sebab seorang hakim cukup mengandalkan perasaannya dalam menjatuhkan hukuman dan jika seorang terdakwa gagal membuktikan bahwa dirinya tidak bersalah melakukan korupsi maka ia otomatis menjadi narapidana. Jadi aparatur penegak hukum itu cukup setingkat debt collector. ${ }^{28}$

Kelemahan asas pembuktian terbalik seperti di atas menunjukkan bahwa penerapannya juga lemah. Hal ini berbeda dengan yang terjadi, misalnya, di Hongkong, Malaysia, dan Singapura di mana negaranegara tersebut sudah terlebih dahulu menerapkan sistem pembuktian terbalik dan sekarang mereka telah berhasil. Di Hongkong, sebagai contoh, sistem pembuktian terbalik diatur dalam Pasal 10 (1b) Prevention of Bribery Ordinance 1970, Added 1974, yang berbunyi: or is in control of pecuniary resources of property disproportionate to bis present or past official emoluments, shall, unless he gives satisfactory explanation to the court as to how he was able to maintain such a standard of living or how such pecuniary resources of property came under his control, be guilty of an offence. Menurut keterangan seorang pejabat Independent Commission Against Corruption Hongkong, penerapan sistem pembuktian terbalik di negara tersebut cukup efektif dalam memberantas tindak pidana korupsi, karena seseorang akan takut melakukan korupsi. Hal itu disebabkan karena akan sulit baginya memberikan penjelasan yang

${ }^{28}$ Luhut MP Pangaribuan, "Sistem Pembuktian Terbalik", Kompas, 2 April 2001, 1. 
memuaskan kepada penegak hukum tentang sumber kekayaannya jika memang kekayaannya itu diperoleh dengan cara dan dari sumber yang tidak sah. ${ }^{29}$ Ketentuan tersebut memperlihatkan bahwa menguasai sumber-sumber pendapatan atau harta yang tidak sebanding dengan penghasilan (gaji) pada saat seseorang menjabat maupun pendapatan resmi di masa ia tidak lagi menjabat akan dinyatakan sebagai perbuatan bersalah dan pelanggaran, kecuali jika ia dapat memberikan suatu penjelasan yang memuaskan kepada pengadilan mengenai bagaimana ia mampu memperoleh standar hidup yang demikian itu atau bagaimana sumber-sumber pendapatan atau harta itu dapat ia kuasai.

Di negara-negara Anglo Saxon, perbuatan suap menjadi kendala terhadap pembuktiannya di pengadilan, sehingga muncul istilah gratifikas $^{30}$ yang kemudian diadopsi di Indonesia, khususnya pada Undang-undang Nomor 20 Tahun 2001 tentang Tindak Pidana Korupsi sebagaimana yang diatur dalam Pasal 12 B dan 12 C. Pasal ini oleh para ahli hukum dianggap sebagai pasal mandul, karena salah dalam penulisan kebijakan legislasinya. Atas dasar argumentasi tersebut dapat disimpulkan bahwa penerapan pembuktian terbalik pada prinsipnya tidak dapat dijustifikasi, karena bertentangan dengan asas non self-incrimination dan keterkaitannya dengan asas praduga tak bersalah (principle of lawfulness).

Di satu pihak, penerapan pembuktian terbalik terhadap tindak pidana korupsi memang akan merugikan terdakwa, karena hak-haknya kurang terlindungi, tetapi di lain pihak hal ini akan membawa kebahagiaan atau kemanfaatan bagi banyak orang, karena dapat mengurangi tindak pidana korupsi yang telah begitu banyak merugikan negara. Untuk dapat menerapkan pembuktian terbalik terhadap tindak pidana korupsi perlu dikaji terlebih dahulu, karena terdapat beberapa masalah; pertama, bagaimana pihak kejaksaan membiasakan diri dari pola yang sebelumnya; kedua, kesiapan seluruh perangkat penegak hukum dengan penerapan sistem tersebut; dan ketiga, jangan sampai

\footnotetext{
29 Romli Atmasasmita, "Pembuktian Terbalik Kasus Korupsi", Harian Seputar Indonesia, 27 September 2006, 2.

${ }^{30}$ Dalam bahasa Belanda adalah gratificatie, yaitu hadiah atau pemberian uang. Lihat Sudarsono, Kamus Hukum (Jakarta: Renika Cipta, Cet. Ke-5, 2007), 149. Ketika membahas gratifikasi, tentu terkait erat dengan aparat pemerintah (pegawai negeri sipil), di mana sebagai aparat pelayan masyarakat belum menjadi seperti yang masyarakat harapkan. Kenyataannya, fasilitas pelayanan publik di Indonesia masih sangat memprihatinkan. Bahkan, tidak jarang, hanya untuk mendapatkan kemudahan dan pelayanan terbaik masyarakat harus menggunakan "uang pelicin" atau uang jasa.
} 
pembuktian terbalik ini justru menjadi "alat pemerasan" baru di mana semua orang dapat saja disudutkan melakukan korupsi dan dalam hal ini pihak kejaksaan tidak akan dianggap bersalah dengan menuduhkan berbagai macam tindak korupsi terhadap seseorang. Orang yang dituduh melakukan korupsi diminta untuk membuktikan di muka pengadilan bahwa ia tidak melakukan korupsi, sehingga hal ini dapat memunculkan banyak "pemerasan" dengan dalih tuduhan melakukan korupsi. $^{31}$ Selain itu, menurut Todung Mulia Lubis, penerapan asas pembuktian terbalik ini tidak mudah, karena selama ini laporan kekayaan pejabat tidak dibuat. Dengan demikian, sulit dipisahkan antara kekayaan pribadi dengan kekayaan-kekayaan "haram" yang diperoleh seseorang ketika ia menjabat jabatan publik. Oleh karena itu, seharusnya disyaratkan adanya laporan kekayaan pejabat sebelum ia menjabat dan diumumkan kekayaannya tersebut secara berkala (misalnya setiap tahun) kepada publik sehingga harta pejabat itu bisa diaudit dan diinvestigasi. ${ }^{32}$

Di Indonesia, wacana penerapan pembuktian terbalik atas harta para pejabat negara mencuat dan menjadi perdebatan panjang di masa pemerintahan Presiden Abdurrahman Wahid (Gus Dur). Ketika itu Gus Dur pernah mengajukan draft Peraturan Pemerintah Pengganti Undang-undang (Perpu) mengenai pembuktian terbalik dalam penanganan dan pemberantasan tindak pidana korupsi. Namun, berbagai kalangan merasa pesimis terhadap draft Perpu yang diajukan tersebut, disebabkan oleh anggapan bahwa asas pembuktian terbalik melanggar hak-hak dasar seseorang yang dibentengi oleh asas praduga tak bersalah (presumption of innocence). Meskipun, di lain pihak, pengajuan draft tersebut disambut terbuka dari berbagai pihak, namun pada akhirnya rancangan Perpu tersebut ditolak. Upaya yang sama juga pernah dilakukan oleh KPK untuk mempercepat pemberantasan korupsi. KPK mengusulkan penggunaan asas pembuktian terbalik pada tahun 2004 silam, namun hingga saat ini usulan KPK tersebut tidak terealisasi.

Tidak terealisasikannya usulan penerapan asas pembuktian terbalik dalam sistem hukum di Indonesia diakibatkan oleh banyak faktor penghambat, seperti: pertama, bahwa kewajiban beban

31 Topo Santoso, "Pembuktian Terbalik Hanya Pengalihan Isu", Jakarta Post, 5 April $2001,1$.

32 T. Mulia Lubis, Pembuktian Terbalik Tidak Mudah, http://www.hukumonline.com/ diakses pada 5 April 2001. 
pembuktian terbalik tidaklah dikenal dalam sistem hukum di Indonesia. Celah untuk menggunakan asas pembuktian terbalik, telah dikunci rapat dalam Kitab Undang-undang Hukum Pidana (KUHP). Pada pasal 66 KHUP ditegaskan bahwa tersangka atau terdakwa tidak dibebani kewajiban pembuktian. Dengan demikian, seseorang yang telah disangkakan telah melakukan tindak pidana, tidak memiliki kewajiban untuk melakukan pembuktian terbalik. Kedua, penggunaan asas pembuktian terbalik dianggap melanggar hak-hak dasar seseorang. Terlebih jika hal tersebut dikaitkan dengan asas presumption of innocence atau asas praduga tak bersalah. Dalam kovenan internasional, hal tersebut juga telah dinyatakan dalam International Covenant on Civil and Political Rights (ICCPR), yang telah diratifikasi melalui Undang-undang Nomor 12 tahun 2005. Artinya, ICCPR tersebut menjamin sepenuhnya hak seseorang untuk tidak dinyatakan bersalah sebelum terbukti secara hukum (non selfincrimination). Pasal 14 ayat (3) huruf $g$ ICCPR menyebutkan bahwa: Dalam penentuan tuduhan pelanggaran pidana terhadapnya, setiap orang berbak untuk tidak dipaksa memberikan kesaksian terbadap diri sendiri atau mengaku bersalab. ${ }^{33}$

Ketiga, adanya problematika hukum, yakni meskipun celah untuk memberlakukan asas pembuktian terbalik terdapat pada sejumlah klausul undang-undang negara Indonesia, akan tetapi secara universal berlaku asas hukum lex superior derogat legi inferiori atau peraturan hukum yang tingkatannya lebih rendah harus tunduk kepada peraturan hukum yang lebih tinggi. Dengan kata lain, peraturan tersebut tidak boleh melanggar ketentuan yang berada di atasnya. Dalam Undang-undang Nomor 10 tahun 2004 tentang Pembentukan Peraturan Perundangundangan, Pasal 7 ayat (1), disebutkan bahwa jenis dan hierarki perundang-undangan terdiri dari UUD 1945, UU/Perpu, PP, Perpres dan Peraturan Daerah. Dengan demikian, aturan dalam bentuk apapun untuk mengakomodasi asas pembuktian terbalik akan dipersoalkan, karena melanggar ketentuan UUD 1945 sebagai dasar tertinggi dalam penyelenggaraan hukum Negara Republik Indonesia.

Polemik penerapan pembuktian terbalik yang sudah lama terjadi dan argumentasi-argumentasi hukum yang diungkapkan para pakar hukum di negeri ini pada dasarnya tidak dapat dijadikan alasan penghambat terhadap penerapan pembuktian terbalik untuk diatur dalam sebuah peraturan perundang-undangan. Pemikiran-pemikiran yang hanya disandarkan pada pandangan positivisme hukum tidak bisa

${ }^{33}$ Human Right, Fair Trial, 23. 
dijadikan sebagai tameng penghambat pengaturan asas pembuktian terbalik untuk dituangkan dalam UU yang baru; apalagi menjustifikasinya sebagai hal yang bertentangan dengan asas praduga tidak bersalah (presumption of innocence) dan asas non self-incrimination; dua hal yang yang tidak boleh dilakukan dalam suatu proses peradilan pidana.

Penerapan asas non self-incrimination dalam pengertian terbatas juga mengandung hak dan kewajiban hukum di dalamnya, sesuai dengan fungsi hukum yang memberikan pembatasan. Hal ini berdasarkan ketentuan dalam Undang-undang Nomor 28 tahun 2009 tentang Penyelenggaraan Negara yang Bersih dan Bebas dari Korupsi, Kolusi, dan Nepotisme (KKN), di mana dengan jelas Pasal 5 Ayat (3) menyebutkan bahwa: "Setiap penyelenggara negara berkewajiban untuk melaporkan dan mengumumkan kekayaan sebelum dan sesudah menjabat". Meskipun ketentuan dalam pasal ini dianggap telah tidak berfungsi lagi, namun keberadaannya tetap menjadi suatu materi hukum sehingga untuk selanjutnya dipertegas kembali melalui dan/atau dalam Undang-undang Nomor 20 tahun 2001 dalam Pasal 37, 37 A, 38 A, 38 B dan 38 C.

Terlepas dari adanya faktor penghambat dalam implementasi pembuktian terbalik, ada usaha pemberantasan korupsi yang patut diapresiasi. Contoh yang membanggakan adalah pembongkaran kasus dugaan korupsi yang sudah mengakar dan sangat akut di Kementerian Keuangan. Pembongkaran dugaan korupsi tersebut tentu memerlukan keberanian penegak hukum, semisal Susno Duadji (mantan Kabareskrim Mabes Polri) yang menjadi whistle blower dalam usaha membongkar kasus korupsi tersebut. Ketegasan para pengawas internal untuk melakukan pengusutan dan menindaklanjuti hasil pemeriksaannya kepada KPK dan/atau Kejaksaan, dalam hal ini, sangat menetukan keberhasilan setiap usaha pembongkaran dugaan tindak pidana korupsi. Apabila pengawas internal tidak dapat mengungkap, maka perlu adanya tindakan tegas kepada tersangka yaitu keharusannya membuktikan asal perolehan harta kekayaan yang dia miliki.

Semua pihak sepakat bahwa perbuatan korupsi merupakan bentuk pelanggaran terhadap hak-hak orang banyak (publik). Oleh karena itu, pemerintah dituntut bersikap lebih serius dalam melakukan tindakan pencegahan maupun penghukuman yang ekstrem terhadap pelakunya demi tegaknya hukum (law enforcement) di Indonesia. Tanpa bermaksud meragukan kredibilitas dan kapabilitas Pemerintah 
Indonesia, penulis berpandangan bahwa Indonesia_dalam konteks pemberantasan tindak pidana korupsi-mungkin dapat mengikuti model yang diterapkan di Republik Rakyat Cina di mana seratus peti mati dan satu peti khusus untuk pemimpinnya (baca presidennya, penulis) telah disiapkan bagi pejabat publik yang terbukti secara legal telah melakukan tindak pidana korupsi. ${ }^{34}$

Di Indonesia sekarang ini banyak elit politik atau para pejabat negara yang disangka dan/atau terbukti melakukan tindakan korupsi berbicara tentang HAM. Menurut penulis, hal seperti ini merupakan fenomena lucu dan kontradiktif di mana sebagai orang yang telah melawan hukum, yaitu para koruptor tersebut, masih mencoba mencari celah supaya dirinya tidak dapat dijerat oleh hukum dengan alasan melanggar HAM. Sementara itu, di sisi lain banyak pakar hukum berbicara mengenai sistem pembuktian terbalik dalam kasus korupsi akan tetapi pandangan mereka ditanggapi secara sinis, apatis, dan skeptis. Penulis, dalam hal ini, mendukung diadakannya pemetaan dan penataan ulang mengenai wacana penerapan asas pembuktian terbalik, walaupun hal ini bertentangan dengan konstitusi dan HAM. Alasannya adalah karena dalam penegakan hukum yang bersifat khusus, yaitu pemberantasan tindak pidana korupsi, sangat diperlukan sebuah sistem yang tegas di mana di antaranya adalah pembuktian terbalik.

Pembuktian terbalik, apabila terdapat pada civil law system, memang merupakan suatu dilema. Hal ini karena pada sistem civil law tidak dikenal adanya sistem pembuktian terbalik; karena suatu negara pada masa ke depan ingin mengaplikasikan apa yang disebut dengan welfare state. Menurut penulis, konstruksi pembangunan welfare state sebaiknya tidak terkooptasi pada sistem hukum tertentu, sebab generalisasi terhadap suatu sistem hukum akan menciptakan kontradiksi di dalamnya. Hendaknya hal ini dipahami sebagai suatu paradigma baru sebagai upaya pencapaian welfare state tersebut. Dalam hal ini, harus ada paradigma hukum yang kognitif, aplikatif, dan apresiatif dalam pembangunan hukum di Indonesia pada masa mendatang serta tidak terdorong oleh mobokrasi di mana hal itu dilakukan hanya untuk melindungi kepentingan sekelompok status quo.

Selama ini, Hukum Acara Pidana sebenarnya hanya menunjukkan jalan untuk berusaha mendekati sebanyak mungkin persesuaian dengan kebenaran. Hukum pembuktian memberi petunjuk bagaimana hakim

${ }^{34}$ Mohammad Atik Fajardin, "Efek Jera Bagi Koruptor dengan Siapkan Peti Mati", Sindonews, 24 Juli 2013. 
dapat menetapkan sesuatu hal yang cenderung kepada kebenaran. Dalam menilai kekuatan pembuktian tersebut dikenal beberapa sistem atau asas pembuktian, yaitu:

Pertama, asas pembuktian yang hanya berdasarkan kepada alat-alat pembuktian yang disebut oleh Undang-undang secara positif (positief wettelijk bewijstheorie). Artinya, jika telah terbukti suatu perbuatan sesuai dengan alat-alat bukti yang disebut oleh Undang-undang, maka keyakinan hakim tidak diperlukan sama sekali. Asas ini disebut juga asas pembuktian formil (formele bewijstheorie). Asas ini berusaha menyingkirkan segala pertimbangan hakim yang bersifat subyektif, oleh karena itu mengikat secara tegas supaya hakim hanya tergantung pada ada atau tidak adanya sejumlah alat bukti yang formil tercantum dalam Undang-undang cukup untuk menjatuhkan putusan. ${ }^{35}$ Wirjono Prodjodikoro menolak asas ini untuk dianut di Indonesia, karena menurutnya hakim hanya dapat menetapkan kebenaran dengan cara mengatakan kepada keyakinannya tentang kebenaran itu, lagi pula keyakinan seorang hakim yang jujur dan berpengalaman mungkin sekali adalah sesuai dengan keyakinan masyarakat. ${ }^{36}$

Kedua, asas pembuktian berdasar keyakinan hakim semata-mata (conviction intime). Artinya, jika dalam pertimbangan keputusan hakim telah menganggap terbukti sesuatu perbuatan sesuai dengan keyakinan yang timbul dari hati nurani seorang hakim, maka dapat dijatuhkan putusan. Sistem ini menurut Martiman Prodjohamidjojo tidak dianut dalam peradilan umum ataupun dalam KUHAP. Contoh dari sistem ini dipergunakan dalam peradilan yuri. ${ }^{37}$ Sedangkan menurut Wirjono Prodjodikoro sistem pembuktian demikian pernah dianut di Indonesia yaitu pada peradilan distrik dan peradilan kabupaten. Sistem ini memungkinkan hakim menyebut apa saja yang menjadi dasar keyakinannya, misalnya keterangan medium atau dukun. ${ }^{38}$

Ketiga, asas pembuktian berdasar keyakinan hakim dalam batasbatas tertentu atas alasan yang logis (conviction raisonee). Asas ini disandarkan pada keyakinan hakim atas dasar pertimbangan akal atau menurut logika yang tepat (berendeneerde overtuiging) dan memberikan keleluasaan kepada hakim secara bebas untuk menggunakaan alat bukti yang lain.

\footnotetext{
35 Poernomo, Pertumbuban Hukum, 40.

36 Andi Hamzah, Hukum Acara Pidana Indonesia (Jakarta: Sapta Artha Jaya, 1996), 259.

${ }^{37}$ Prodjohamidjojo, Sistem Pembuktian, 16.

${ }^{38}$ Hamzah, Hukum Acara Pidana, 260.
} 
Keempat, asas pembuktian berdasar keyakinan hakim yang timbul dari alat-alat bukti dalam Undang-undang secara negatif (negatief wettelijk bewijs theori). Dalam sistem ini ada dua hal yang merupakan syarat, yaitu; wettelijk, yaitu alat-alat bukti yang sah dan ditetapkan oleh Undang-undang; dan negatief, maksudnya dengan alat-alat bukti yang sah dan ditetapkan Undang-undang saja belum cukup untuk memaksa hakim pidana menganggap bukti sudah diberikan, tapi masih dibutuhkan adanya keyakinan hakim. ${ }^{39}$

Dari keempat asas pembuktian di atas, ketentuan Hukum Acara Pidana Indonesia mengikuti prinsip dari teori negatief wettelijk bewijs theorie. Hal ini dapat dilihat dari ketentuan Pasal 183 KUHAP bahwa "Hakim tidak boleh menjatuhkan putusan pidana kepada seseorang kecuali apabila dengan sekurang-kurangnya dua alat bukti yang sah ia memperoleh keyakinan bahwa suatu tindak pidana benar-benar terjadi dan bahwa terdakwalah yang bersalah melakukannya". Oleh karena itu, berdasarkan ketentuan tersebut di atas, maka dalam Pasal 183 KUHAP terdapat dua unsur, yaitu sekurang-kurangnya ada dua alat bukti yang sah, dan dengan dasar alat bukti yang sah itu hakim yakin bahwa tindak pidana telah terjadi dan terdakwa telah bersalah. Sehingga dengan demikian antara alat-alat bukti dan keyakinan hakim harus ada hubungan causal (sebab-akibat) terhadap suatu pembuktian.

Permasalahan seperti dikemukakan di atas kemudian mendapat pencerahaan, yaitu melalui berbagai dukungan dan dipertegas dengan dikeluarkannya fatwa Majelis Ulama Indonesia (MUI). ${ }^{40}$ MUI menilai bahwa pembuktian terbalik itu diperlukan untuk membuktikan harta yang dimiliki para pejabat adalah sah, bukan hasil korupsi atau diperoleh dengan cara yang tidak wajar.

Mengacu pada teori zawâjir dan jawâbir dan asas min ayn lak hâdha, maka pencegahan dan pemberantasan jarimah korupsi di Indonesia dapat dilakukan secara menyeluruh, yaitu dengan cara merekonstrukasi aturan-aturan yang sudah ada dengan mengislamkan hukum-hukum anti-korupsi melalui metodologi ilmiah yang dapat dipertanggungjawabkan secara hukum. Di samping itu, untuk mengaplikasikan metode pembuktian terbalik dalam kerangka negara Indonesia, para pejabat sebaiknya diwajibkan untuk menyerahkan laporan harta kekayaannya ke lembaga terkait seperti Komisi Pemberantasan

\footnotetext{
${ }^{39}$ Prodjohamidjojo, Sistem Pembuktian, 14.

40 Fatwa MUI tersebut dijelaskan oleh Ma'ruf Amin (Ketua Bidang Fatwa MUI Pusat) dalam acara Munas-8 MUI, di Jakarta, Rabu 28 Juli 2010.
} 
Korupsi (KPK), agar dapat memberikan suatu gambaran yang kuat bahwa harta yang dimilikinya selama menjadi pejabat adalah dalam konteks kewajaran atau tidak.

\section{Penutup}

Dalam sejarah perkembangan hukum Islam dikenal beberapa teori dan asas penerapan sanksi dan pembuktian dalam pidana korupsi, seperti teori zawâjir dan jawâbir serta asas min ayn lak hâdhâ. Hal yang sangat penting dalam penerapan sanksi pidana korupsi adalah asas yang disebut terakhir. Asas ini merupakan pemahaman terhadap konteks "asas pembuktian terbalik" sebagaimana dilakukan pada masa kekhalifahan 'Umar b. al-Khattâb dalam mencegah dan memberantas terjadinya jarimah korupsi bagi para bawahannya.

Teori-teori dan asas dalam hukum Islam seperti dikemukakan di atas sangat mungkin untuk diimplimentasikan dalam peraturan perundang-undangan tindak pidana korupsi di Indonesia. Kemungkinan tersebut didasarkan pada argumen bahwa penerapan sanksi pidana hukum Islam sangat elastis, dinamis, sistematis, dan memiliki masa depan bagi negara Indonesia yang mayoritas penduduknya beragama Islam, di samping bahwa hukum Islam telah menjadi bagian dari sistem hukum nasional. Hal ini dimaksudkan agar teori-teori dan asas dalam hukum Islam dapat ditransformasikan ke dalam peraturan perundang-undangan pemberantasan tindak pidana korupsi di Indonesia sebagai proses penegakan hukum korupsi yang kuat dan komprehensif. Menurut hemat penulis, upaya rekonstruksi peraturan perundang-undangan korupsi di Indonesia merupakan hal yang sangat urgen dan mendesak; hal ini dalam rangka pencegahan dan pemberantasan korupsi yang terkesan kuat sudah membudaya namun sulit untuk dideteksi.

\section{Daftar Rujukan}

'A'la, Rofiqul. "Suap dalam Pespektif Islam" dalam A.S. Burhan dkk, ed., Korupsi di Negeri kaum Beragama: Ikbtiar Membangun Fiqh Anti Korupsi. Jakarta: P3M dan Kemitraan-Partnership, 2004.

'Amîr (al), 'Abd al-'Azîz. al-Ta 'zîr fî al-Sharî' ab al-Islâmîyah. Kairo: Dâr al-Fikr al-'Arabî, 1976.

Amiruddin, Hasbi. Republik Umar bin Khattab. Yogyakarta: Total Media, 2010.

Atmasasmita, Romli. "Pembuktian Terbalik Kasus Korupsi", Harian Seputar Indonesia, 27 September 2006. 
Azra, Azyumardi. "Umar bin Khattab: Konsep dan Praksis Ketatanegaraan", dalam Hasbi Amiruddin, Republik Umar bin Khattab. Yogyakarta: Total Media, 2010.

Baltaji, Muhammad. Metodologi Ijtihad Umar bin al-Khathab, terj. Masturi Irham. Jakarta: KHALIFA, 2005.

Bassar, M. Sudradjat. Hukum Pidana: Pelengkap KUHP. Bandung: Armico, 1983.

Basyir, Ahmad Azhar. Ikbtisar Fikih Jinayat: Hukum Pidana Islam. Yogyakarta: UII Press, 2001.

Bukhârî (al), Abû 'Abd Allâh Muhammad b. Ismấîl b. Ibrâhîm b. Mughîrah. Șahîh al-Bukhârî, Vol. 1. t.t.: Dâr al-Fikr, t.th.

Din, Muhammad. Stimulasi Pembangunan Hukum Pidana Nasional dari Aceh untuk Indonesia. Bandung: UNPAD PRESS 2009.

Fajardin, Mohammad Atik. "Efek Jera Bagi Koruptor dengan Siapkan Peti Mati", Sindonews, 24 Juli 2013.

Hadîd (al), Ibn Abî. Sharḥ Nahj al-Balâghah, Vol. 1. Kairo: Dâr Ihyầ’ alKitâb al-'Arabîyah, 1959.

Hạjâaj (al), 'Abd al-Ḥusayn Muslim b. Șahîh Muslim, Vol. 5. Damaskus: Dâr al-Fikr, t.th.

Hamzah, Andi. Hukum Acara Pidana Indonesia. Jakarta: Sapta Artha Jaya, 1996.

Irfan, M. Nurul. Korupsi dalam Hukum Pidana Islam. Jakarta: Amzah, 2011.

Kansil, C.S.T. Pengantar Ilmu Hukum dan Tata Hukum Indonesia. Jakarta: Balai Pustaka, 1989.

Lawyer Committee for Human Right, Fair Trial: Prinsip-prinsip Peradilan yang Adil dan Tidak Memibak, terj. Ahmad Fauzan. Jakarta: Yayasan Lembaga Bantuan Hukum Indonesia, 1997.

Lubis, T. Mulia. Pembuktian Terbalik Tidak Mudah, http://www.hukum online.com/diakses pada 5 April 2001.

Mursî, Muhammad Saî̀. Tokoh-tokoh Besar Islam Sepanjang Sejarah, terj. Khoirul Amru Harahap dan Achmad Faozan. Jakarta: Pustaka Al-Kautsar, 2007.

Musharrafah, 'Atîyah Muṣtafâ. al-Qaḍ̂ fî al-Islâm. T.tp: Shirkah alSharq al-Awsât, 1966.

Nasrullah. "Tindak Pidana Korupsi dalam Hukum Islam dan Peraturan Perundang-undangan Republik Indonesia: Studi Kritis Hukum Islam terhadap Undang-undang No. 31 Tahun 1999 Jo Undang-undang No. 20 Tahun 2001 tentang Pemberantasan 
Tindak Pidana Korupsi”, Disertasi. Banda Aceh--Program Pascasarjana IAIN Ar-Raniry, 2013.

Pangaribuan, Luhut MP. "Sistem Pembuktian Terbalik", Kompas, 2 April 2001, 1.

Poernomo, Bambang. Pertumbuhan Hukum Penyimpangan di Luar Kodifikasi Hukum Pidana. Jakarta: Bina Aksara, 1986.

Praja, Juhaya S. Teori-teori Hukum: Suatu Telaah Perbandingan dengan

Pendekatan Filsafat. Bandung: Pascasarjana Universitas Islam Negeri, 2009.

Prodjohamidjojo, Martiman. Sistem Pembuktian dan Alat Bukti. Jakarta: Ghalia Indonesia, 1983.

Santoso, Topo. "Pembuktian Terbalik Hanya Pengalihan Isu", Jakarta Post, 5 April 2001, 1.

Shâtibîi (al), Abû Ishââ. al-Muwâfaqât fî Ușûl al-Sharî‘ah, Vol. 2. Beirût: Dâr al-Kutûb al-'Ilmîyah, t.th.

Sudarsono. Kamus Hukum. Jakarta: Renika Cipta, Cet. Ke-5, 2007.

Suyûtị (al), Jalâl al-Dîn. Târîkh al-Khulafâ'. Kairo: Dâr al-Kutûb alSalafiyah, t.th.

Taqwaddin. Esensi Hukum Rajam. Lhokseumawe: Serambi, 2009.

Zarqâ (al), Muṣtafâ Aḥmad. al-Madkhal al-Fiqhî al-'Ám, Vol. 2. Damaskus: Dâr al-Fikr, Cet. Ke-2, 1968. 